\title{
Gendered Articulations of Control and Care on Social Media During the COVID-19 Pandemic in Hungary
}

\author{
Katinka Linnamäki * \\ Department of Social Sciences, Institute of Political Sciences, University of Helsinki, Helsinki, Finland
}

\section{OPEN ACCESS}

Edited by:

Dario Quattromani,

Università Link Campus, Italy

Reviewed by:

Aaron Erlich,

McGill University, Canada

Kristin Makszin,

Leiden University, Netherlands

*Correspondence:

Katinka Linnamäki

katinka.linnamaki@helsinki.fi

Specialty section:

This article was submitted to

Comparative Governance,

a section of the journal

Frontiers in Political Science

Received: 21 January 2021

Accepted: 06 May 2021

Published: 07 June 2021

Citation:

Linnamäki K (2021) Gendered Articulations of Control and Care on Social Media During the COVID-19

Pandemic in Hungary.

Front. Polit. Sci. 3:656731.

doi: 10.3389/fpos.2021.656731
The purpose of this paper is to examine the Hungarian Fidesz-KDNP government's discursive practices of control and care during the first wave of the COVID-19 pandemic. The paper researches the Hungarian government's communication on the official Hungarian COVID-19 Facebook page during the first wave of the pandemic. Its aim is to answer the question how the Hungarian government articulated control and care to reinforce sedimented gendered division of care work and institutions of control to tackle the potential disruption of the system of care before the widespread vaccination of the elderly population was available in the country. The paper argues that the pandemic has allowed the government to exert control in areas, such as the crisis in the workforce market and health care system, as well as in the destabilized system of care work. The main finding is that in the material the government performs control over care work, whose intensified discussion during the pandemic could lead to a potential disruption within the illiberal logic on two different levels. First, physical care work related to immediate physical needs, like hunger, clothing, pain enacted by female shoppers, female health care workers and female social workers, is newly defined during the pandemic as local, family-bound and a naturally female task. Second, the government articulates care work, either as potentially harmful (for the elderly population and thus indirectly to the government's familialist politics), or as vulnerable and in need of protection from outside influences (portrayed through the interaction of health care workers and "hospital commanders"). This enables the government to perform full state control over care workers through the mobilization of police and military masculinity and to strengthen and re-naturalize the already existing hierarchies between traditional gender roles from a new perspective during the pandemic. This state of affairs highlights the vulnerability both of the elderly population, on whom its familialism builds, and of the system of informal care work, which builds on the unpaid care work of female citizens, who paradoxically are also articulated as potential harm for the elderly and for the system.

Keywords: COVID-19, gender, Hungary, care work, control, familialism, illiberal democracy 


\section{INTRODUCTION}

Established gender roles highly contribute to the level of economic, health, and physical risks certain social groups face during a pandemic (Davies and Bennett 2016; Smith 2019; Connor et al., 2020). Women in Europe and the United States, limited by sedimented and unquestioned social gender norms, are, for instance, often expected to augment their caregiving roles during disease outbreaks (Smith, 2019; Connor et al., 2020). During national lockdowns due to the outbreak of the 2019 novel coronavirus disease (COVID-19) additional care-related tasks, such as daytime childcare, have been the responsibility of women as well. It has resulted in a higher "caregiver burden" women in general need to face, that is a "multidimensional toll that caregivers experience to their social, emotional, spiritual, financial, and physical wellbeing" (Adelman Ronald et al., 2014; Connor et al., 2020). Julia Roth (2020) states that the COVID-19 pandemic is not just a health-related crisis, but functions "as a sort of prism or burning glass though which manifold systemic and structural pitfalls, inequalities and injustices became visible in new dimensions". She points out that, as a consequence, the COVID-19 pandemic made topics that have "often been reduced to feminist niches," such as gendered care work and the divisions of labor, more visible for the general public. This was clearly the case in Hungary, for example, especially after the closure of secondary schools when such gender disparities became immanent (Milanovich 2020; Roth 2020; Ti mit csináltok, 2020; UNICEF 2020). Moreover, some scholars even state that the pandemic has the potential to disrupt certain implicit pacts regarding the division of care work among genders and generations within and beyond families (Alon et al., 2020; Gregor and Kováts 2020). ${ }^{1}$

In Hungary, due to the economic tolls caused by the COVID19 pandemic, the state has decreased its social services, which has resulted in an increasing amount of unpaid and informal care work falling on women, especially in areas of childcare, elderly care, and health care (Ti mit csináltok, 2020; Fodor et al., 2021). Moreover, the cases from Hungary show how women tend to leave their lower income jobs more often than their male partners to provide extra care work for the family during the pandemic (Gregor and Kováts 2020; Ti mit csináltok, 2020). As

${ }^{1}$ The effect of the COVID-19 pandemic on intensifying established gender order has resulted in Hungary, and in many other countries, in an increase of reported cases of domestic violence against women (Nók elleni erőszak, 2020). This “shadow pandemic" (Özkazanç-Pan and Pullen 2020) is often associated with the lockdown regulations in many countries around the world. The explanation is that being locked up together increases violence in families, which is often affected by culturally sedimented gendered ways of coping with the increased levels of stress during the pandemic (Nök elleni eröszak, 2020; Özkazanç-Pan and Pullen 2020). According to research, men often abuse alcohol to cope with increasing levels of stress associated with financial difficulties (Dunaway, 2018) and isolation (Posfai, 2020) during pandemic outbreaks or economic recessions. Moreover, due to the decreased opening hours or the shut down of public service providers during lockdown - in Hungary this includes courts - reporting cases of domestic violence is also harder and even the progress of reported cases is slower than usual. Hence, many victims face isolation leading to even more stress and violence (Nők elleni erőszak, 2020; Posfai 2020). recent research points out, even though on average Hungarian men have also increased their contributions to household duties, women's contribution still grew significantly more than theirs and the pandemic has generally increased gender inequalities in terms of domestic care work (Fodor et al., 2021). The gender inequalities within the Hungarian informal care system became unsustainable after the closure of schools and the isolation of the elderly from the rest of the population in March 2020 (Ti mit csináltok, 2020). These two events have played an especially important factor in the organization of care work, as the contribution of elderly family members to care work within families, often manifested as childcare, cooking or help with children with disabilities (Ti mit csináltok, 2020), formed one of the bases of the Hungarian government's social and family politics (Dupcsik and Tóth 2008; Gregor and Kováts 2020). However, as the elderly fall into the risk group, this population needs to stay in their own homes, even if they are healthy and mobile. This not only results in their isolation and the demand for extra care of their needs from the municipality-this care usually being provided by women working in daycare (Ti mit csináltok, 2020) but also in the suspension of the contribution of the elderly to the care work in many families. This dramatic change, paired with the closure of schools, results in additional childcare and teaching duties falling on families (ÓnodyMolnár 2020). This situation could potentially lead to a crisis in the current informal caregiving system and the social politics of the government, which strongly builds on familialism, traditional division of work and the unpaid care work of women (Dupcsik and Tóth 2008; Grzebalska and Pető 2018; Gregor and Kováts 2020).

According to Roth (2020), the pandemic brought to light an institutionalized lack of gender equality and the crisis of systems of care work in many countries, which could potentially be used by anti-hegemonic right-wing populist groups to mobilize people against the hegemonic power holders. This points to the argument that gender as a "symbolic glue" often serves to affectively mobilize nationalistic, religious or anti-immigration policies (Korolczuk and Graff 2018, 799; Gunnarsson Payne et al., 2019; Aharoni and Féron 2020). Roth (2020) also argues that conservative political actors in hegemonic positions, in order to take control over the possible disruptions during the pandemic, need to reinforce and re-naturalize the idea of "the heteronormative family and the respective role models" as well as "the feminization and racialization of care work." In Hungary the right-wing Fidesz-KDNP government has stabilized its hegemonic position and has since 2010 won the parliamentary elections with a landslide on three consecutive occasions. Thus, from their perspective the visibility of inequalities within the care work system can be seen as a threat that potentially disrupts their familialist social politics and opens up the discursive field to antihegemonic voices within the country. Accordingly, the government framed the COVID-19 pandemic as yet another crisis (similar to recent political, financial, or natural crises) (Orbán 2020, 00:2:20-25) that destabilizes the country's health, economic and legislative system (Koronavírus, 2020, March 23). This paper argues that the pandemic has allowed the government to exert control in other areas, such as the crisis in the workforce 
market and health care system, as well as in the destabilized system of care work. The paper researches the Hungarian government's communication on the official Hungarian COVID-19 Facebook page during the first wave of the pandemic. Its aim is to answer the question how the Hungarian government articulated control and care to reinforce sedimented gendered division of care work and institutions of control to tackle the potential disruption of the system of care before the widespread vaccination of the elderly population was available in the country. ${ }^{2}$

\section{HUNGARY}

The political landscape of Hungary is described as an illiberal democracy, a hybrid political system where an exceptional degree of power is concentrated within a parliamentarian democratic setting (Krekó and Enyedi 2018, 39). The idea of transforming Hungary into an "illiberal state" originates from PM Viktor Orbán, who defined illiberalism as a state-organizing logic that is based on nationalism, community, work, and Christian values, rather than liberal values, such as freedom, that are dominant in Western-European states (Orbán 2014). The "illiberal turn" in the Hungarian polity started in 2010 with the landslide electoral victory of the right-wing Fiatal Demokraták Szövetsége (FIDESZ)-Kereszténydemokrata Néppárt (KDNP) coalition over the left-liberal camp (Laczó, 2018). The illiberal turn means an increasing centralization of political power and a decrease in checks and balances, indicted by the government's growing control over the courts, media and civil society. A lack of pluralism was justified by renewing the perceived threats against the polity, and a change in the electoral rules and the Constitution permanently weakened the political opposition. These changes have been in power for the last three electoral cycles (Bustikova and Guasti 2017, 168-174). In Hungary, the illiberal hegemony is constituted through the exclusionary imperative of "liberal" values and a "symbolic-constitutive rejection of the liberal left as illegitimate to rule or participate in (defining 'real') democracy" within and beyond the country's borders (Palonen 2018, 9). The rejection of liberal values and a return to Christianity and a workbased society has also affected the Fidesz-KDNP government's gender politics. Even though in Hungary, as opposed to the rest of Central and Eastern Europe, so far there are no civil anti-gender movements, current research draws attention to the anti-gender right-wing political discourse of the Fidesz-KDNP government (Kováts and Petö 2017). The government connects the term "gender" to the ideological control of the liberal European Union (Félix 2015; Kováts and Peto" 2017). Therefore, after their landslide victory in 2010 they launched their family mainstreaming policies as a reaction to the allegedly antifamily and anti-Christian gender mainstreaming policies of the

${ }^{2}$ During the second wave of the pandemic similar governmental tendencies concerning control and care can be observed. However, the government set up a rapid vaccination process for the elderly and for teachers, which also suggests that the government did take some actions to tackle the disrupted system of care work.
EU. Family mainstreaming has offered an illiberal solution to the problem of declining demography, which it sees in increasing the birth rate as opposed to immigration, which it connects to the EU’s liberal gender mainstreaming (Juhász 2012; Grzebalska and Petö 2018).

Accordingly, scholars see ideological familialism as "a form of biopolitics which views the traditional family as a foundation of the nation, and subjugates individual reproductive and selfdetermination rights to the normative demand of the reproduction of the nation" as a "key tenet of the illiberal project" (Kemper 2016; Grzebalska and Petö 2018, 167). In Hungary, however, besides ideological familialism a strong social familialism is present as well that is rooted in a widespread lack of social trust (Dupcsik and Tóth 2008). This means that family relations enjoy more strength and trust in the country than any other social relations, which are often based on obligation and are easy to destabilize (Dupcsik and Tóth 2008). This leads to a generally positive attitude among Hungarian citizens towards the family as a value as well as traditional gender roles associated with families, independently of their stand on gender equality (Dupcsik and Tóth 2008; 2014). Thus, traditional gender-based work division within families has remained generally intact in the country, even if the employment status or stand on gender equality shows variety among Hungarian citizens (Dupcsik and Tóth 2014). In general, more than $75 \%$ of care work, most typically laundry, cooking, and cleaning, is done by females, a division which typically none of the family members finds unfair (Dupcsik and Tóth 2014, 231). Accordingly, the Fidesz-KDNP government's family mainstreaming policies can be understood as a way to combine ideological familialism in the name of illiberalism with a strongly present social familialism in citizens' attitudes in order to gain electoral popularity. In the name of family mainstreaming, a Family Protection Bill became part of the Hungarian Constitution in 2013, which defines "family" from a traditional, heteronormative and Christian perspective. In 2012 the Catholic Church's influential Lexicon (2003) was translated into Hungarian. ${ }^{3}$ The publication, which has triggered antigender civil movements throughout Europe (Kuhar and Paternotte 2017), introduces the doctrine of complementarianism, a central demand of current anti-gender movements throughout Europe (Kuhar and Paternotte 2017). Complementarianism, which has replaced the doctrine of female subordination, acknowledges basic women's rights and their equally important work in public life as that of men. However, it also stresses the naturally different nature of men and women and especially women's "special responsibilities for the family" (Case 2016, 7-8). The fact that the Lexicon's most important parts on gender roles have been translated separately and published in advance in a journal for caring professionals (Kováts and Pető 2017, 119), points to the government's highly gendered understanding of care work both within and beyond families. Even though later on the government highlighted the idea that family mainstreaming does not oppose but nourishes gender

\footnotetext{
${ }^{3}$ Lexicon of the Family, Családlexikon 2012
} 
equality (Kováts and Pető 2017, 122), the government's understanding of gender equality is comprehensible only within Christian teachings on gender complementarianism (Case 2016 13), as its gender polices "are often framed in a way that assumes and reaffirms traditional gender roles" (Grzebalska and Pető 2018, 167). As these roles disadvantage female citizens with higher education (Grzebalska and Petö 2018) and lessen the chances of women with children to re-enter the labor market, leading to a marginalization for women with small children (Fodor and Kispeter 2014), the family policies of the government only benefit women in traditional caregiver roles, in particular, as “mothers" (Grzebalska and Peto 2018).

However, in spite of the widely spread ideological and social familialism that results in generally positive attitudes towards traditional gender roles and a gender-based division of labor within families, the COVID-19 pandemic has initiated still ongoing public discussions on the systematic inequalities and limitations of the informal caregiving system (Laborczi 2020; Milanovich 2020; Ti mit csináltok, 2020; UNICEF 2020; Ónody-Molnár 2020; Bánlaki, 2021; Szabó, 2021). From the perspective of ideological familialism, discussions problematizing the power structures within traditional family constellations, that is, the amount of care work falling on women and the unfair division of labor between family members and between families and the state, mean a threat to familialism. Emancipatory discussions tend to see families as potential spaces of oppression, while familialism defines them as emotional units (Dupcsik and Tóth 2008). Moreover, emancipatory discussions potentially lead to the emergence of other (feminist) ideologies that could challenge the ideology of familialism, a challenge which, according to research, has been historically missing from Hungarian social and political discourses (Dupcsik and Tóth 2008). Thus, the turbulent gender-related consequences of the pandemic could potentially renew the gender mainstreaming versus family mainstreaming discourses and shed light on how the government's family mainstreaming in effect hinders gender equality (Kováts and Petö 2017, 122; Ti mit csináltok” 2020). The government, instead of addressing the need for more female care workers during the pandemic (Ónódy-Molnár, 2020), tried to prevent discussions about the crisis in care work (Laborczi 2020; Milanovich 2020; Ti mit csináltok, 2020; UNICEF 2020; Ónódy-Molnár, 2020) by, for example, framing the closure of schools as fulfilling a request initiated by concerned (caregiver) parents (Grád-Kovács 2020; Ti mit csináltok, 2020), supporting and reinforcing their caregiver roles. Moreover, in its discursive practices the government also tried to re-naturalize traditional gender roles and feminize care work. It is these discursive practices that this paper aims to analyze.

\section{MATERIALS AND METHODS}

To capture the core ideas that the Fidesz-KDNP government has communicated during the pandemic and to embed the manifest content of their communication into its illiberal and anti-gender politics, I used the method of qualitative content analysis (Drisko and Maschi 2015). This holistic view on the communicated content favors the explanatory research design this paper is applying, in which the knowledge about the context in which the content is embedded is more clearly defined than in a basic and descriptive content analysis (Drisko and Maschi 2015, 91; Krippendorff 2013). Following the methodological steps of iterative qualitative sampling (Drisko and Maschi 2015), I defined my sample based on a cyclical process between data collection and data analysis. Collecting data from several sources, such as the official Hungarian COVID19 homepage, the homepage of the government and several Facebook pages using the iterative sampling process, I decided to concentrate on the official Hungarian Facebook site on the COVID-19 pandemic as the source of material for the analysis. The page is maintained by the government and it provides the most material for analyzing the research question, namely the gender aspects of the government's control, which is often articulated implicitly, and can be best captured through the analysis of the published visual material. In addition, recent research points out that Facebook is the most relevant and widely used social media in Hungary (Lévai 2018). Accordingly, the platform plays a crucial role in communication during the pandemic: the state of emergency was announced on the Facebook page in a video format; official announcements from both the Hungarian PM, Viktor Orbán, and the Operational Group (the Operational Group Responsible for Defense against the Coronavirus-infection; in Hungarian: A Koronavírus-fertőzés Elleni Védekezésért Felelős Operatív Törzs) were also live-streamed on Facebook. According to the Facebook page's own introduction, the audience can read "trustworthy, controlled information in connection to the novel coronavirus and the defense against it" (Koronavírus 2020). The site defines itself as a governmental page and as the official Facebook page of the Operational Group. The Facebook page actively promotes the official governmental homepage on COVID-19 in Hungary, which serves as a source for the information published on this Facebook page and with which the content of its daily shared information often corresponds. The Facebook page, however, publishes more visual and less written content than the COVID-19 homepage. With more than 212,000 followers, the page has a relatively wide outreach in the country and received more than 190,000 likes by the end of 2020. According to visitors' ratings, the page has a higher than average rating, obtaining 3.6 out of 5 stars. This number shows among the 126 respondents who rated the page how many recommended or did not recommend it, either by leaving a recommendation on the page itself or recommending it to other friends on Facebook. The biggest criticism from people who did not recommend the page is that the information posted is not objective and that the page instead creates panic, either by "blowing up" the importance of the coronavirus or by spreading governmental "propaganda" (Koronavírus 2020). Nevertheless, the posts receive a high level of reader engagement. On average each post from March and April, the most active phase of information sharing during the research period, has received more than 
1,000 likes, more than 250 comments and was shared almost 180 times. $^{4}$

I collected data from the page between 11 March and 18 June 2020, indicating the launch day of the Facebook page and the date when the state of emergency and the Enabling Act were withdrawn in Hungary (Koronavírus 2020). That is, the material concentrates on the first wave of the pandemic in Hungary. However, in terms of the findings, the performativity of control and its gender aspects continued throughout 2020 as well. The material from the data collection period consists of 365 posts and 757 images. ${ }^{5}$ The largest amount of information was published in March and April. As of 30 April 2020 , the situation in the country stabilized and the national lockdown was lifted; in May and June the number of posts significantly decreased. First, I coded the posts as holistic entities, meaning that I coded both the published images and the texts they contain with nominal themes to describe the structure of the data. Throughout this phase I applied a combined deductive-inductive coding plan, combining previous preconceptions focusing on the theme of control and their gender aspects, such as the portrayal of male and female figures and their gender roles with an inductive "open-coding" approach to the data (Strauss and Corbin 1998; Drisko and Maschi 2015). In March the main themes were the case of a group of Iranian exchange students who were first diagnosed with the virus in the country and apparently refused to cooperate with the police; the announcement of the state of emergency and the closure of schools, which happened on the 16th of March; and the risk elderly people face combined with the reported extra care for them within the families as well as in the country. In April the most frequently mentioned theme was the lockdown, paired with photos showing law enforcement workers in operation, referring to the government's heightened legislative control over the pandemic and over citizens during the lockdown. A large number of the posts were dedicated to the theme of available health care instruments and the state of facilities in the hospitals, such as the government's control over the crisis through imported health care supplies and newly built hospitals. In addition, the visual portrayal of the work of health care workers became a regularly occurring theme. Later the economic action plan of the government was introduced, portraying the government as being in control of the financial consequences of the pandemic. At this time, the discussion on the elderly moved to the discussion on

\footnotetext{
${ }^{4}$ In comparison, posts on the most popular Facebook page in Hungary, that of the airplane company Wizz Air, with over 3 million likes, had on average similar user engagement numbers just before the pandemic outbreak in the country (Wizz Air Facebook statistics, 2021).

${ }^{5}$ This paper is designed in line with the most recent ethical guidelines on social media research (Townsend and Wallace 2016) and the privacy policies of the online platforms from which the material is collected (e.g., "Terms of Service" 2019). As all actors included in the research are public figures and the COVID-19 Facebook page is openly accessible for the public with hundreds of thousands of followers, it is reasonable to consider the data from there as public. As the aim of, and reasonable expectation for, the platform is to reach as many people as possible with their contents, the data are not considered sensitive and their direct republication is not considered to pose any potential harm to their publisher (cf. Townsend and Wallace 2016).
}

elderly homes, which became a hotspot for the virus and where most COVID-19 patients died during the researched time period. Visual portrayals of several elderly homes were published on a regular basis, presenting the investigating, and controlling national bodies taking over control in these institutions. In May the economic action plan, and especially the need and established possibilities for work were thematized the most, portraying the government as calm and optimistic about taking back control over the virus. In June mostly practical information was posted about the reopening of restaurants and borders. The government ended the state of emergency and numerous posts reported the successful defense against the virus, portraying the government as successfully controlling the virus.

As the next step, I qualitatively analyzed the connections and conflicts between the content categories (Krippendorff, 2013). The epistemology that guided the analysis and interpretation was the discourse theory of Laclau and Mouffe (1985). The analysis was based on the theoretical categories of discourse, articulation, and nodal point, which I will briefly define before presenting the results. Laclau and Mouffe (1985) displace the term "ideology" with "discourse" when talking about hegemonic struggles and thus they open up "reality as a site of [discursive] struggle" (DeLuca, 1999, 334). Importantly, discourse is not restricted to speech but is understood as "both the use of words and the actions" (Laclau 2006, 106), based on which (Palonen, 2019, 181) highlights the material means and consequences of its meaningmaking processes. Using this understanding of discourse, the paper analyzes the posted texts and images in relation to the government's legislative actions, which I conceptualize both as a contextual background to and as part of the government's discourse, often occurring within the material. In Laclauian discourse theory, meaning is created through articulation, a practice that links together certain contingent-linguistic and non-linguistic, natural and social-elements into a partially fixed system. This system is established through relationality among the elements, which relations establish (fix) their meaning (Howarth, 2014, 5). Such meaning-producing relations are organized around a nodal point, meaning certain privileged signs that other signs in the articulation are ordered around, and whose meanings are defined in relation to them (Laclau and Mouffe 1985, 112-113). The nodal point I was concentrating on when designing the study was control, and during the analysis I particularly examined how the system of care work is included in the government's articulation of control. Accordingly, during the analysis I focused on the relation of the content categories care and control and my goal was to answer the question how their connections shed light on the gender aspects of control and how they potentially address the gender-related consequences of the pandemic.

\section{RESULTS}

\section{Gendering control and care}

In its articulation of control, the Hungarian government has widely used war metaphors during the pandemic, which, 
according to recent literature (Van Rythoven 2020), can serve to reduce the insecurities by connecting the time of the pandemic to well-known war-related collective memories and images (Goode et al., 2020). Already the introduction of the emergency law that refers to Articles 48-54 of the Constitution, which "provide for special emergency powers in case of an imminent danger of war and external armed attack and in the event of a natural or industrial disaster" (Kovács B., 2020), invoked the "war against the pandemic" metaphor, as it did in several other countries in Europe as well. Moreover, in January 2020 the government appointed the Coronavirus Operational Group, responsible for the defense against the disease, consisting of "many more army commanders in uniforms than healthcare professionals" (Kovács B., 2020). Since the state of emergency, three members of the Coronavirus Operational Group held a live-streamed session on national television every day at noon, where they reported on the latest progress of the pandemic, announced new rules and regulations, and gave advice for the time of the quarantine. They regularly appeared in the posts of the Coronavirus Facebook Page. Most of their press conferences were streamed live and stored to the page in video format, and captured stills of the members with added citations from the press conferences were used as visual material for the posts. The trio consisted of two male law enforcement workers, often a police officer and a soldier, and Cecilia Müller, the national Chief Medical Officer, leader of the National Public Health Center, who, due to her practical everyday advice and caring manner, became "the grandmother of the country" (Presinszky 2020). Müller is usually pictured in news about the health aspects of the virus, either reporting on its general spread in the country (e.g.: Koronavírus, 2020, April 3); drawing attention to the heightened care that the elderly population requires (Koronavírus, 2020, March 28); giving practical advice to families how to take care of them (Koronavírus, 2020, April 1); giving instructions on how to visit their family members in hospitals (Koronavírus, 2020, March 11); informing the public about the available health care services (Koronavírus, 2020a, May $15)$; or emphasizing and thanking the "devoted work" of the health care workers throughout the pandemic (Koronavírus, 2020a, May 12). The images of Róbert Kiss, Police Lieutenant Colonel and Tibor Lakatos, Colonel in their police uniforms, on the other hand, illustrate news on stricter border control (Koronavírus, 2020, April 21); or statistics on how many people were sanctioned for breaking the restrictions (Koronavírus, 2020, March 30; Koronavírus, 2020a, April 19). This gender division attributed to news about health care and control reflects the gendered articulation of care and control, which is striking in the imagery used by the government during the pandemic.

\section{Control}

References to a fight against the virus are constant on the COVID-19 Facebook page as well. In March 2020, for instance, Orbán announced that defense against the virus was organized on four fronts: police, military, health care and economic (Koronavírus, 2020, March 23). Since then, the presence of law enforcement and military masculinities significantly increased in the media in general, and accordingly, on the Facebook page as well, as military masculinity took over control on all four of the abovementioned fronts. Thus, the visual articulation of control is strikingly gendered: the images illustrating the posts in this category represent police officers (85\%) and soldiers (95\%) with male actors.

First, police officers were portrayed as embodiments of legislative control over the pandemic. Since $4 \mathrm{March}$, as a heightened level of control was announced to be necessary, the power of law enforcement forces was widened, and emergency laws were introduced. In the material, police control was initially exerted over the first diagnosed COVID-19 patients, the "noncooperative" Iranian students (Koronavírus, 2020, March 9). Their behavior in the hospital was framed as a crime by the Hungarian police and the short criminal proceedings ended with the controversial and, according to the civil protection organization Helsinki Committee, illegal deportation of 13 Iranian citizens from the country (Koronavírus, 2020, March 8; Az iráni diákok kollektív kiutasítása, 2020). Besides, control was regularly performed over people in home quarantine, in the material usually by publishing data on how many people had been ordered to stay in home quarantine and how many of them did not obey the laws, making police interventions necessary. The visual illustrations usually feature images of police officers (Koronavírus, 2020, March 20; Koronavírus, 2020a, April 23; Koronavírus, 2020, May 14). ${ }^{6}$ Further, since 28 March a strict lockdown was introduced: people could only leave for work and shopping purposes, which were patrolled by police officers (MTI 2020). Since 27 April the usage of obligatory masks was also controlled and the absence of masks was penalized by police officers first only in Budapest, but later extension to a national level was also discussed (Kötelező maszkviselést, 2020; Kötelezővé teszik, 2020). In the material, regular reports were published on how many people violated the lockdown and face-mask rules and were sanctioned by heavy fines or were involved in criminal proceedings (e.g. Koronavírus, 2020, April 8; Koronavírus, 2020b, April 19). The visual illustration of the information contains albums with 5-10 images portraying sanctioning and disciplining police and military authorities walking on the streets, interrogating people, or potentially giving out fines (Koronavírus, 2020, April 7; Koronavírus, 2020, April 8; Koronavírus, 2020b April 19).

Second, another frequent war-related metaphor is the war over the health supplies. Orbán, for example, frames health masks imported from China as "the loot of the Eastern raids" (Koronavírus, 2020, March 24). The military is highly involved in controlling and distributing the necessary health supplements, and military forces are portrayed as helping the government by taking supplies from airplanes and distributing them among health care facilities, such as hospitals and homes for the

\footnotetext{
${ }^{6}$ To reinforce the war rhetoric, it is worth noting that those in compulsory home quarantine needed to post a sign from the authorities ("a red card") on their door, which can easily be connected with the segregation of Jewish citizens during the Second World War (Kovács K., 2020).
} 
elderly. Military forces also took over control of hospitals. On 30 March Hungarian military officers were appointed as "hospital commanders" to the head of each hospital. These positions were filled either by police officers or soldiers and were represented, apart from one image, by male figures, reflecting the social reality of gendered work segregation in Hungary (AEEK 2019). Officially, their task is to control and manage the material and human resources of the hospitals (Béres 2020), activities which are also regularly photo-documented on the Facebook page (e.g.: Koronavírus 2020, March 30, Photo album: "Védöeszközök és a kórházparancsnokok"). Further, military forces also built an emergency hospital in the small town of Kiskunhalas within two and a half weeks of Orbán personally visiting (Koronavírus, 2020, April 11) and regularly disinfected homes for the elderly, which was also thoroughly documented in visual albums in the material (e.g.: Koronavírus, 2020 April 17). Finally, on the economic front, military officers took control over the production of the country's strategic companies, such as the Hungarian Oil Company (MOL) and directed it to produce disinfection liquids (MOL Hygi) that they then distributed to hospitals and homes for the elderly (e.g.: Koronavírus, 2020, April 16, Photo album: "Fertőtlenítőszerek is érkeznek a kórházakba"). In addition, the Hungarian Army has stepped up as a strategic new employer for everyone who was left without a job after the pandemic (Koronavírus, 2020b, April 23; Koronavírus, 2020, May 19). The articulation of control thus connected the government's more controlling (centralized) legislative measures with its aspiration to control (or lessen) the pandemic's negative health-related and economic consequences. This gives control a double meaning: its meaning as lessening freedom, that is regulation, causally relates to its meaning as lessening damage, that is protection, a more outward looking and conflict-oriented version of care. Control, both in terms of regulation and protection, is connected to masculinized state institutions, such as the police and the military, which masculinizes control and embeds it into a conflict-based, militarized war-topology.

\section{Care}

Following the example of Cecilia Müller, besides military and police masculinities, femininized health care workers are portrayed in a large number of Facebook posts with photo albums capturing them during work, containing 9-15 individual images each (e.g.: 30 April 2020, Photo album: "Sok a munka a Szent János Kórházban is”). On the textual level, the group of health care workers who are particularly thanked due to their "devoted work" are the nurses, family doctors and the trained volunteers who work as auxiliary nurses during the pandemic (Koronavírus, 2020, April 30; Koronavírus, 2020b, May 12). This list concentrates on health care workers either with the least amount of education in health care (nurses and volunteers), or who are employed by local municipalities as opposed to the state (family doctors), engaging with the direct needs of the patient, as opposed to specialists or doctors (Kovács K., 2020; Blaskó 2020). Visually, health care workers in direct physical contact with patients are almost exclusively portrayed through female figures, performing the gendered act of care work: bending down to patients with a smile and touching them gently (e.g.: Koronavírus, 2020a, May 15, Photo: No title added), whereas among the patients there was no significant difference in terms of gender representation. This reflects the binary social reality, as according to statistical data there are significantly more female than male workers among nurses, however there are more male workers among doctors (AEEK 2019). Importantly, however, although their body is almost fully covered with the protective gear obligatory in hospitals when working with COVID-19 patients, thanks to various tactics in their portrayal, their bodies are still visibly gendered. Such tactics are, for instance, close shots of the facial area, close shots of the hair area that makes the length of the hair visible even if it is covered by a protective cap, or in some cases shots of handmade writings (for instance "Dr Dóri") and drawings (for example a flower) on the protective gear, the flower assumedly being made by and referring to the person who wears it (Koronavírus 2020, April 30, Photo: No title added). ${ }^{7}$ Care is thus strongly feminized in its articulation. Care work is articulated as it does not require high education and, in contrast to the masculinized state institutions of control, is organized locally by the municipalities, both in the cases of the hospitals as well as the homes for the elderly. Care differs from the protective understanding of control-which is articulated as conflictoriented, focusing on threat and organized on the state level-as it is based on help and compassion, focuses on those in need, and is connected to the personal and physical dimensions of direct interactions.

\section{Controlling care}

Firstly, the articulation of control in relation to care sheds further light on how the masculinized institutions of control and the feminized interpersonal tasks of care relate to each other. Importantly, in the visual representation of law enforcement workers during their controlling and sanctioning activities in public spaces, 77 percent of the civilians they encounter are female figures. These figures are often pictured during their shopping activities either near a supermarket carrying shopping bags or in a market hall browsing among goods. The reason behind the high number of such images is the regulation that restricted the time to between 9 and 12 a.m. for only the elderly population to visit the stores. To ensure that citizens follow this regulation, law enforcement workers organized systematic raids in market halls, food stores, and pharmacies (e.g.: Koronavírus, 2020, March 31, Photo album: “A kijárási korlátozás 4 . napja"). As these locations are visited mostly by female citizens-in any age group-providing care work for their families, the illustration usually portrays female figures during typically female everyday activities, such as doing the shopping and browsing among products. This is counterbalanced with a

\footnotetext{
${ }^{7}$ When male and female health care workers are portrayed together, a certain gendered hierarchy is visible among them with the male body occupying a central and higher position, whereas female bodies-usually more than one near to a single male body-occupy the lower positions of the listener or the assisting helper, for instance when the male figure is getting into his protective gear (Koronavírus 2020b; May 15, Photo: No title added).
} 
controlling male figure, usually a police officer, talking to the female figure. The figure of the police officer is usually portrayed as taller or bigger and with a more relaxed body composition than the female figure, which establishes a hierarchized and gendered connection between care and control (e.g.: Koronavírus 2020, April 2, Photo: No title added). On the textual level, this portrayal is framed as an act of caring protection as, for instance, the following image description shows: "The police uses "reassuring, helpful, empathetic and loyal measures" to encourage the public to comply with the curfew" (Koronavírus, 2020, April 2, Photo: No title added). Besides, as women who are portrayed on such images are labelled as "elderly people" in the description, these images articulate control as "empathetic" protection first and foremost, of the elderly population (e.g.: Koronavírus, 2020; March 29, Photo: No title added). However, in some images younger women are portrayed, and the capitation of those images refers to the sanctioning meaning of control, such as: "In the last 24 hours, police officers have taken action in 1255 cases against those who violated the rules of curfew" (Koronavírus 2020, April 10). Accordingly, these portrayals might represent younger female figures as potential harm towards the elderly, who they endanger if they do their shopping outside the permitted hours. This means also a potential harm indirectly towards the government's politics of care, because this politics centers on the contribution of the elderly to care work within families and thus depends on the safety of this population (Dupcsik and Toth 2008; Grzebalska and Pető 2018; Gregor and Kováts 2020).

Secondly, another theme that pictures control as protection of the elderly, and thus indirectly of the government's politics of care, relates to the mass COVID-19 infection in old people's homes caused by not following hygiene rules in several of these institutions. Controlling groups representing the "epidemiological authority of the government" were sent to many of these institutions to check the professional competence of the care workers in the institutions and whether they complied with the epidemiological and hygiene rules ordered by the government (e.g.: Koronavírus, 2020, April 11, Photo album: "Ellenőrzés a Pesti úti idősotthonban"). Members of the controlling group are often portrayed with the elderly residents of the institutions. In such cases, they are pictured in a caring position, for instance with a smile, and use various techniques to lower their body position, such as taking a seated position, or bending over towards the residents (e.g.: Koronavírus 2020, June 18, Photo: No title added). Accordingly, control is articulated again as care and protection towards the elderly. However, when portrayed with social workers, the posture of the controllers' change. In their portrayal, social workers, mostly women, are pictured in lower body positions, for instance lowering their heads or looking upwards towards the controlling figures (e.g.: Koronavírus 2020, May 14, Photo: No title added). On the contrary, members of the controlling groups are pictured in higher body positions, and even if they are not homogenously gendered-meaning there are just as many female as male figures among them-they are portrayed as bigger in comparison to the female social workers. Further, they often carry sheets of papers with them while questioning the social workers (e.g.: Koronavírus 2020, May 14, Photo: No title added). Thus, the hierarchy between care and control is immanent. Besides, the feminization of care work is again striking as all social workers portrayed in the material are female. Moreover, the social workers are wearing more homey outfits, for instance, slippers, and only a face mask to protect themselves. By contrast, the controlling figures are always wearing full-body protective gears, gloves, covered outside shoes and hair protection (e.g.: Koronavírus, May 14, 2020, Photo: No title added). This portrayal can refer to a gendered private-public differentiation between care and control. In addition, repeated posts reported that doctors were not present at old people's homes in Budapest during the time of the official control, so they could not execute professional medical control over the residents and over colleagues (e.g.: Koronavírus, 2020a, April 24). This further emphasizes that care work in its most direct and physical form (such as the care work provided by social workers, nurses, and volunteers during the pandemic) needs professional control either from a doctor, or from the government's authorities.

Thirdly, the hierarchical relation between care and control is expanded from physical care work to health care in general when law enforcement workers appeared in the hospitals. According to the COVID-19 Facebook page, the appointed "hospital commanders" fulfilled two roles. On the one hand, they provided hospitals with enough medical and protective gear to protect health care workers who are in direct contact with the patients, who, as I showed above, are mainly gendered as female. On the other hand, they ease the workload of medical directors and hospital directors, who are exclusively male actors in the material, which again reflects the existing hierarchized gender segregation within Hungarian health care (AEEK 2019). This articulation of control further nuances its meaning: control as a means of protection is targeted at feminized health care workers, whereas with male hospital directors, control acquires the meaning of help and assistance. When female health care workers are portrayed with "hospital commanders," they are usually placed in the background as passive figures, watching the male figures and waiting for them, for example, to unpack protective gear (e.g.: Koronavírus 2020, April 3, Photo: No title added). On the other hand, images of "hospital commanders" offering help to the hospital directors picture them on a similar eye level, as coworkers, which is also signaled by their shared activities (e.g.: Koronavírus 2020, March 30, Photo: "Fábián Bertold rendör alezredes"). Thus, whereas protection refers to a built-in hierarchy between protector and protected, help and assistance is portrayed as cooperation between two equals.

Finally, the articulation of control and care has a geographic dimension as well. For instance, the largest old people's homes with the highest numbers of infections and death cases are in the capital. Here the frequent negative portrayal offered an opportunity to highlight a Budapest versus countryside division in the material. Furthermore, discourses on homes for the elderly also emphasized the centralized nature of control over the locally organized care work, as the management of old people's homes and the care of the elderly in general (for example, home deliveries, etc.) were reportedly the responsibility of the municipalities and not the government. Thus, performances of control became the exclusive 
responsibility of the centralized government, who controlled local municipalities, who in turn performed care work (Koronavírus, 2020, March 25). The geographic differentiation has its gender aspects as well. People in the countryside are pictured as female and are referred to in the material as in need of help. They are portrayed as waving to police officers from their doorsteps, who according to the description of the images visit them to offer help (e.g.: Koronavírus 2020, April 20, Photo: No title added). The capital area, however, is continuously referred to as a place "where police officers have a lot to do" in terms of controlling and sanctioning those who do not cooperate with the lockdown regulations. They are often shown to be women, for example jogging outside in front of a huge outdoor banner that says, "Stay home" (Koronavírus 2020 April 2, Photo: "Koronavírus - Maradj otthon!"), walking without masks (Koronavírus 2020, April 7, Photo: No title added) or getting a fine (Koronavírus, 2020 April 10).

In conclusion, in the analyzed material, control is articulated both as regulation and protection, tightly bound to the masculinized state institutions of the police and the military. In relation to care, which is articulated in a highly feminized way, on the one hand, control means protection: first and foremost, the protection of elderly people, but also of care workers, and citizens from the countryside. On the other hand, control regulates and sanctions care work when it is portrayed as a potential harm to the elderly population. Care work as a potential harm is performed by young female citizens who shop in the time frame reserved for the elderly, and by female social workers in old people's homes who do not comply with hygiene rules. Care and control are articulated in a gendered way both on the visual and on the textual level of the material. On a visual level, caregivers are portrayed as women in their own environment (wearing slippers and informal clothing), where control appears as an external factor, mostly portrayed by male figures or masculinized positions. On the textual level, nurses are thanked for their "devoted work," where passion and humanity are the most important factors, proven by that fact that even briefly trained volunteers are suitable to execute it (Koronavírus, 2020b, May 12). The work of law enforcement workers, however, is framed as a highly professional duty in the material (Koronavírus, 2020a, April 24), referring to a genderbased differentiation that renders feminized care work to the realm of the informal, private sphere, whereas masculinized control is associated with the institutionalized public sphere. The government performs control over care work, whose intensified discussion during the pandemic could lead to a potential disruption within the illiberal logic on two different levels. First, physical care work related to immediate physical needs, like hunger, clothing, pain, enacted by female shoppers, female health care workers and female social workers, is newly defined during the pandemic as local, family-bound and a naturally female task. Second, the government articulates care work, either as potentially harmful (for the elderly population and thus indirectly to the government's familialist politics), or as vulnerable and in need of protection from outside influences (portrayed through the interaction of health care workers and "hospital commanders"). This enables the government to perform full state control over care workers through the mobilization of police and military masculinity and to strengthen and re-naturalize the already existing hierarchies between traditional gender roles from a new perspective during the pandemic. This state of affairs highlights the vulnerability both of the elderly population, on whom its familialism builds, and of the system of informal care work, which builds on the unpaid care work of female citizens, who paradoxically are also articulated as potential harm for the elderly and for the system.

\section{DISCUSSION}

In this paper I analyzed the Hungarian Fidesz-KDNP government's articulation of control and its relation to care work in the material published on the official governmental Facebook page during the first wave of the COVID-19 pandemic. The material shows that the government has used the pandemic to articulate a new crisis and thus, that the health crisis, often framed as global disruption in everyday practices, served to maintain the continuity of performing control in the country. First, on the level of execution, the government performed strong control by strengthening its centralized illiberal position though the announcement of emergency laws-like the Enabling Act, which provided it with even wider executive powers than before-regulations, and by strictly controlling all public information in connection to the pandemic and sanctioning everyone who did not comply with these rules. Such executive control was performed by the government-controlled state institutions through frequent appearances of law enforcement workers, police and military officers. Second, in relation to care, the articulation of control gained a double, somewhat contradictory meaning. In the material control in relation to care was articulated either as protection, first of the elderly population and second of the health care workers, or as a regulatory and sanctioning act towards female citizens who by performing care work also potentially harm the elderly population and thus indirectly the government's familialist politics. Importantly, the abovementioned articulations of care and control, have an immanent gendered layer. First, portraying care work of the sick and elderly with female figures can be seen as an attempt to feminize care work through re-naturalizing its gendered portrayal and to renaturalize its place in the private sphere to support the government in its neoliberal social politics to give out as little financial support and aid as possible during the pandemic. Second, the feminized care work is also articulated as in need for state control, portraying female citizens, especially those who provide care work in the informal or lower paid professional spheres, as a potential threat towards the elderly and government's familialist politics. Even though further research is needed to elaborate this point, this portrayal might refer to the government's attempt to create new scapegoats for the instabilities of its social care system instead of addressing its shortcomings (Szikra 2018). This potential harm of female citizens to the elderly has a geographic emphasis as well. As "gender mainstreaming" is usually framed as the 
ideological colonialism of the West in Hungary (Kováts and Pető $2017,120)$ and is associated with the urban ruling elite, thus the capital area (Graff et al., 2019), the illiberal anti-elitism intertwines with anti-gender stances. In the material, female citizens are more often portrayed as potentially harmful in the urban than in the rural settings. Further conclusions would require additional research. Still, this portrayal resonates with a recent sociological finding, according to which the pandemic particularly increased the gender inequality in terms of household work in the cities, by increasing the amount of care work especially among middle class, highly educated city dweller females (Fodor et al., 2021, 95). They, accordingly, potentially represent the biggest threat to disrupt the government's social and family politics. In Hungary, the government exerts control over care work, whose intensified discussion during the pandemic could potentially lead to a disruption within the illiberal logic during the first wave of the pandemic, when rapid vaccination of the elderly and of care workers (health care workers, school and kindergarten teachers) was not yet available to stabilize the disrupted system of care work. Sedimented gender roles and control over the care system are successfully reinforced to prevent any possible feminist antihegemonic mobilization within the country. In the long term, this gives an opportunity for the government to strengthen its anti-gender family politics in which care work can be understood as a constellation of private and unpaid crossgenerational and cross-gender transactions, and to create new scapegoats in the portrayal of city dweller female citizens. Further research would, however, be necessary to explore how the visible structural and systemic inequalities influenced feminist anti-hegemonic articulations within the researched period (Roth 2020).

\section{REFERENCES}

Adelman, R. D., Tmanova, L. L. T., Delgado, D., Dion, S., and Lachs, M. S. (2014). Caregiver Burden. JAMA 311 (10), 1052-1060. doi:10.1001/jama.2014.304

AEEK (2019). Beszámoló Az Egészségügyi Ágazati Humánerőforrás 2017. Évi Helyzetéröl [Report on the Situation of Human Resources in the Health Sector in 2017.]. Retrieved from: https://www.enkk.hu/hmr/documents/ beszamolok/HR_beszamolo_2017.pdf (Accessed 09 01, 2020).

Aharoni, S. B., and Féron, É. (2020). National Populism and Gendered Vigilantism: The Case of the Soldiers of Odin in Finland. Cooperation and Conflict 55 (1), 86-106. doi:10.1177/0010836719850207

Alon, T., Doepke, M., Olmstead-Rumsey, J., and Tertilt, M. (2020). The Impact of COVID-19 on Gender Equality. Covid Econ. Vetted Real-Time Pap. 2020 (4), 62-85. doi:10.3386/w26947

Az iráni diákok kollektív kiutasítása (2020). Az Iráni Diákok Kollektív Kiutasítása Jogellenes És Életveszélyes. Magyar Helsinki Bizottság. Retrieved from: https:// helsinki.hu/az-irani-diakok-kollektiv-kiutasitasa-jogellenes-es-eletveszelyes/ (Accessed 04 15, 2021).

Bánlaki, D. S. (2021). A Covidot Is a Nók Hordták Ki? Ideje Megkérdezni Öket, Merre Tovább [Was Covid Carried by Women as Well? It's Time to Ask Them where to Go Next]. Forbes.hu. Retrieved from: https://forbes.hu/legyel-jobb/a-covidot-is-anok-hordtak-ki-ideje-megkerdezni-oket-merre-tovabb/ (Accessed 04 15, 2021).

Béres, M. (2020). "Hosszú Távon Katonai Felügyelet Alá Kerülhet Bármelyik Vállalat" ["In the Long Run, Any Company Can Be under Military Surveillance"]. Magyar narancs. Retrieved from: https://magyarnarancs.hu/ belpol/korhazparancsnokok-honvedek-129728 (Access on 10 01, 2020).

\section{DATA AVAILABILITY STATEMENT}

Publicly available datasets were analyzed in this study. This data can be found here: https://www.facebook.com/koronavirus. gov.hu.

\section{AUTHOR CONTRIBUTIONS}

The author confirms sole responsibility for the following: study conception and design, data collection, analysis and interpretation of results, and manuscript preparation.

\section{FUNDING}

During the writing process the author was funded by the Kone Foundation project, a Now-Time, Us Space: Hegemonic Mobilisations in Central and Eastern Europe (nr.: 201904639) and was supported by the Academy of Finland funded Whirl of Knowledge: Cultural Populism in European Polarised Politics and Societies (WhiKnow) project (nr.: 320275).

\section{ACKNOWLEDGMENTS}

I would like to thank the HEPPsinki research team for their valuable support, my $\mathrm{PhD}$ supervisor, Emilia Palonen and the organizers and participants of the Gender and Populism SKY PhD Seminar at the University of Helsinki for their insights and comments.

Blaskó, Z. (2020). Komoly Feszültségeket Szithat Az Orvosok Között a Januárban Esedékes Béremelés [The Wage Increase Due in January Could Create Serious Tensions Among Doctors]. Mérce, 30. Retrieved from: https://merce.hu/2020/ 12/30/komoly-feszultsegeket-szithat-az-orvosok-kozott-a-januarban-esedekesberemeles/ (Accessed 01 04, 2021).

Bustikova, L., and Guasti, P. (2017). The Illiberal Turn or Swerve in Central Europe? PaG 5 (4), 166-176. doi:10.17645/pag.v5i4.1156

Case, M. A. (2016). The Role of the Popes in the Invention of Complementarity and the Vatican's Anathematization of Gender. University of Chicago, Public Law Working Paper. Religion and Gender Habemus Gender Special, 565. Available at SSRN: https://ssrn.com/abstract=2740008.

Connor, J., Madhavan, S., Mokashi, M., Amanuel, H., Johnson, N. R., Pace, L. E., et al. (2020). Health Risks and Outcomes that Disproportionately Affect Women during the Covid-19 Pandemic: A Review. Soc. Sci. Med. 2020 (266), 113364. doi:10.1016/j.socscimed.2020.113364

Davies, S. E., and Bennett, B. (2016). A Gendered Human Rights Analysis of Ebola and Zika: Locating Gender in Global Health Emergencies. Int. Aff. 92 (5), 1041-1060. doi:10.1111/1468-2346.12704

DeLuca, K. (1999). Articulation Theory: A Discursive Grounding for Rhetorical Practice. Philos. Rhetoric 32 (4), 334-348.

Drisko, W. J., and Maschi, T. (2015). Content Analysis. Oxford: Oxford University Press. doi:10.1093/acprof:oso/9780190215491.001.0001

Dunaway, W. A. (2018). A Félproletár Háztartás a Modern Világrendszer Longue Durée-Je Folyamán [The Semi-proletarian Household during the Longue Durée of the Modern World System]. Fordulat 2018 (24), 53-87.

Dupcsik, C., and Tóth, O. (2014). "Family Systems and Family Values in TwentyFirst-Century Hungary," in Family and Social Change in Socialist and Post- 
Socialist Societies: Change and Continuity in Eastern Europe and East Asia. Editor Z. Rajkai(Leiden: BRILL), 210-249.

Dupcsik, C., and Tóth, O. (2008). Feminizmus Helyett Familizmus. [Familialism Instead of Feminism]. Demográfia 51 (4), 307-328.

Félix, A. (2015). "Hungary," in Gender as Symbolic Glue: The Position and Role of Conservative and Far-Right Parties in the Anti-gender Mobilizations in Europe. Editors E. Kováts and M. Põim (Budapest: Foundation for European Progressive Studies), 62-83.

Fodor, É., Gregor, A., Koltai, J., and Kováts, E. (2021). The Impact of COVID-19 on the Gender Division of Childcare Work in Hungary. Eur. Societies 23 (1), 95-110. doi:10.1080/14616696.2020.1817522

Fodor, É., and Kispeter, E. (2014). Making the 'reserve Army' Invisible: Lengthy Parental Leave and Women's Economic Marginalisation in Hungary. Eur. J. Women's Stud. 21 (4), 382-398. doi:10.1177/1350506814541796

Goode, J. P., Stroup, D. R., and Gaufman, E. (2020). Everyday Nationalism in Unsettled Times: In Search of Normality during Pandemic. Nationalities Pap. Spec. Issue., 1-25. doi:10.1017/nps.2020.40

Grád-Kovács, M. (2020). Orbán: Bezárnak Az Iskolák, Digitális Oktatás Jön [Orbán: Schools Are Closing, Online Education Is Coming]. 24.hu. Retrieved from: https://24.hu/belfold/2020/03/13/Koronavírus-iskolak-bezarasa-tanitasfelfuggesztese/ (Accessed 08 30, 2020).

Graff, A., Kapur, R., and Walters, S. D. (2019). Introduction: Gender and the Rise of the Global Right. Signs: J. Women Cult. Soc. 44 (3), 541-560. doi:10.1086/701152

Gregor, A., and Kováts, E. (2020). Koronajárvány: A Gondoskodási Válság Látványos Leleplezödése. Replika e-book, 127-133.

Grzebalska, W., and Petö, A. (2018). The Gendered Modus Operandi of the Illiberal Transformation in Hungary and Poland. Women's Stud. Int. Forum 2018 (68), 164-172. doi:10.1016/j.wsif.2017.12.001

Gunnarson Payne, Jenny. (2019). Challenging "Gender Ideology": (Anti-) Gender Politics in Europe's Populist Moment. February 10, 2019. The New Pretender. Retrieved from: http://new-pretender.com/2019/02/10/challenging-genderideology-anti-gender-politics-in-europes-populist-moment-jennygunnarsson-payne/ (Accessed 08 30, 2020).

Howarth, D. (2014). "Introduction: Discourse, Hegemony and Populism. Ernesto Laclau's Poliitcal Theory," in Ernesto Laclau: post-Marxism, Populism and Critique. Editor ibid (London: Routledge), 1-21.

Juhász, B. (2012). Orbán's Politics - a Gender Perspective. Friedrich Ebert Foundation Budapest, Working Paper.

Kemper, A. (2016). Foundation of the Nation. How Political Parties and Movements Are Radicalising Others in Favour of Conservative Family Values and against Tolerance, Diversity, and Progressive Gender Politics in Europe. Friedrich Ebert Foundation. http://library.fes.de/pdf-files/dialog/12503.pdf.

Korolczuk, E., and Graff, A. (2018). Gender as "Ebola from Brussels": the Anticolonial Frame and the Rise of Illiberal Populism. Signs: J. Women Cult. Soc. 43 (4), 797-821.

Koronavírus tájékozató oldal [Coronavirus Information Page] (2020). Facebook Page. Facebook. Retrieved from: https://www.facebook.com/Koronavírus.gov. $\mathrm{hu} /$ (Accessed 08 30, 2020).

Koronavírus tájékoztató oldal (2020a). 21 Ezer Orvos [21 Thousand Doctor]. 2020, April 30. Facebook post. Retrieved from: https://www.facebook.com/ Koronavírus.gov.hu/posts/136701754606721 (Accessed 08 30, 2020).

Koronavírus tájékoztató oldal (2020). 21 Ezer Orvos, Ápoló [21 Thousand Doctors, Nurses]. 2020b, May 12. Facebook post. Retrieved from: https://www.facebook. com/koronavirus.gov.hu/posts/136701754606721 (Accessed 08 30, 2020).

Koronavírus tájékoztató oldal (2020). A Hétvégén Általában [On the Weekends Usually]. 2020b, April 19. Facebook post. Retrieved from: https://www.facebook. com/koronavirus.gov.hu/posts/132055845071312 (Accessed 08 30, 2020).

Koronavírus tájékoztató oldal (2020). A Honvédség Várja [The Army Is Awaiting]. 2020, May 19. Facebook post. Retrieved from: https://www.facebook.com/ Koronavírus.gov.hu/posts/143574650586098 (Accessed 08 30, 2020).

Koronavírus tájékoztató oldal (2020). A Kiskunhalasi Mobil Járványkórház [The mobile Epidemic Hospital in Kiskunhalas]. 2020, April 11. Facebook post. Retrieved from: https://www.facebook.com/koronavirus.gov.hu/posts/ 129032122040351 (Accessed 08 30, 2020).

Koronavírus tájékoztató oldal (2020). A Magyar Honvédség [The Hungarian Armed Forces]. 2020b, April 23. Facebook post. Retrieved from: https:// www.facebook.com/koronavirus.gov.hu/posts/133570651586498 (Accessed 08 30, 2020).
Koronavírus tájékoztató oldal (2020). A Nyugat-Európába Tartó [Heading to Western Europe]. 2020, April 21. Facebook post. Retrieved from: https:// www.facebook.com/koronavirus.gov.hu/posts/132781501665413 (Accessed 08 30, 2020).

Koronavírus tájékoztató oldal (2020). A Pesti Út Idösek Otthona Fertötlenitési Munkálatait [Disinfection Works on the Pesti Út Nursing home]. 2020, April 17. Facebook post. Retrieved from: https://www.facebook.com/koronavirus.gov. hu/posts/131400401803523 (Accessed 08 30, 2020).

Koronavírus tájékoztató oldal (2020). A Rendörség Folyamatosan Ellenörzi [The Police Continously Controlls]. 2020a, April 19. Facebook post. Retrieved from: https://www.facebook.com/koronavirus.gov.hu/posts/132038581739705 (Accessed 08 30, 2020).

Koronavírus tájékoztató oldal (2020). A Taxisok Után [After the Taxi Drivers]. 2020, March 23. Facebook post. Retrieved from: https://www.facebook.com/ Koronavírus.gov.hu/posts/120547879555442 (Accessed 08 30, 2020).

Koronavírus tájékoztató oldal (2020a, April 11). Album: "Ellenörzés a Pesti Úti Idösotthonban [Inspection at the Pesti Út Nursing home]". 2020, April 11. Facebook photo album. Retrieved from: https://www.facebook.com/media/set/? vanity=koronavirus.gov.hu\&set=a.129126678697562 (Accessed 08 30, 2020).

Koronavírus tájékoztató oldal (2020). Album: "Fertötlenitöszerek Is Érkeznek a Kórházakba [Also Disinfectants Arrive at Hospitals]”. 2020, April 16. Facebook photo album. Retrieved from: https://www.facebook.com/media/set/? vanity=koronavirus.gov.hu\&set=a.131051401838423 (Accessed 08 30, 2020).

Koronavírus tájékoztató oldal (2020b). Album: "Sok a Munka a Szent János Kórházban Is [There Is Also a Lot of Work at St. John's Hospital]”. 2020, April 30. Facebook photo album. Retrieved from: https://www.facebook.com/ media/set/?vanity=koronavirus.gov.hu\&set=a.136684054608491 (Accessed 08 30, 2020).

Koronavírus tájékoztató oldal (2020a). Album: "Védöeszközök És a Kórházparancsnokok Érkeztek a Kórházakba [Protective Equipment and Hospital Commanders Arrived at the Hospitals]". 2020, March 30. Facebook Album. Retrieved from: https://www.facebook.com/koronavirus.gov.hu/ photos/a.124108379199392/124108589199371 (Accessed 08 30, 2020).

Koronavírus tájékoztató oldal (2020). Az Állampolgárok Többsége [The Majority of Citizens]. 2020, March 30. Facebook post. Retrieved from: https://www. facebook.com/koronavirus.gov.hu/posts/124045725872324 (Accessed 08 30, 2020).

Koronavírus tájékoztató oldal (2020). Az Elmúlt 24 Órában [In the Last 24 hours]. 2020, April 10. Facebook post. Retrieved from: https://www.facebook.com/ koronavirus.gov.hu/posts/128566792086884 (Accessed 08 30, 2020).

Koronavírus tájékoztató oldal (2020). Dr. Müller Cecília. 2020, March 11. Facebook post. Retrieved from: https://www.facebook.com/koronavirus.gov.hu/posts/ 114332760176954 (Accessed 08 30, 2020).

Koronavírus tájékoztató oldal (2020). Eddig 1200 Emberrel Szemben Kellett Intézkedni [So Far, 1200 People Had to Take Action against]. 2020a, April 23. Facebook post. Retrieved from: https://www.facebook.com/koronavirus. gov.hu/posts/133600191583544 (Accessed 08 30, 2020).

Koronavírus tájékoztató oldal (2020). Egyre Többen Szegik Meg [More and More People Are Breaking it]. 2020, April 8. Facebook post. Retrieved from: https:// www.facebook.com/koronavirus.gov.hu/posts/127764418833788 (Accessed 08 30, 2020).

Koronavírus tájékoztató oldal (2020). Hogyan Tudjuk Védeni [How Can We Protect]. 2020, April 1. Facebook post. Retrieved from: https://www. facebook.com/koronavirus.gov.hu/posts/124995529110677 (Accessed 08 30, 2020).

Koronavírus tájékoztató oldal (2020). Jelenleg 11 Ezren Vannak [At the Moment There Are 11 Thousand]. 2020, May 14. Facebook post. Retrieved from: https:// www.facebook.com/koronavirus.gov.hu/posts/141654624111434 (Accessed 0830,2020 ).

Koronavírus tájékoztató oldal (2020). Kérjük Az Idöseket [We Ask the Elderly]. 2020, March 28. Facebook post. Retrieved from: https://www.facebook.com/ koronavirus.gov.hu/posts/123171189293111 (Accessed 08 30, 2020).

Koronavírus tájékoztató oldal (2020). Kijárási Korlátozás [Lockdown]. 2020, March 25. Facebook post. Retrieved from: https://www.facebook.com/koronavirus. gov.hu/posts/121525262791037 (Accessed 08 30, 2020).

Koronavírus tájékoztató oldal (2020). Köszönet a Rendöröknek [Thanks to the Police]. 2020a, April 24. Facebook post. Retrieved from: https://www.facebook. com/koronavirus.gov.hu/posts/134236798186550 (Accessed 08 30, 2020). 
Koronavírus tájékoztató oldal (2020). Köszönjük Az Ápolónőknek [We Thank the Nurses]. 2020a, May 12. Facebook post. Retrieved from: https://www.facebook. com/Koronavírus.gov.hu/posts/140830094193887 (Accessed 08 30, 2020).

Koronavírus tájékoztató oldal (2020). Lakatos Tibor. 2020, March 8. Facebook post. Retrieved from: https://www.facebook.com/koronavirus.gov.hu/posts/ 113446340265596 (Accessed 08 30, 2020).

Koronavírus tájékoztató oldal (2020). Lakatos Tibor. 2020, March 20. Facebook post. Retrieved from: https://www.facebook.com/koronavirus.gov.hu/posts/ 119198696357027 (Accessed 08 30, 2020).

Koronavírus tájékoztató oldal (2020). Május 18-tól [From 18 May on]. 2020, May 15. Facebook post. Retrieved from: https://www.facebook.com/koronavirus. gov.hu/posts/141992337410996 (Accessed 08 30, 2020).

Koronavírus tájékoztató oldal (2020). No Title Added. May 14, 2020. Facebook photo. Retrieved from: https://www.facebook.com/Koronavírus.gov.hu/ photos/141700570773506 (Accessed 08 30, 2020).

Koronavírus tájékoztató oldal (2020). No Title Added. 2020a, May 15. Facebook photo. Retrieved from: https://www.facebook.com/Koronavírus.gov.hu/ photos/141973214079575 (Accessed 08 30, 2020).

Koronavírus tájékoztató oldal (2020). No Title Added. Album: "A Kijárási Korlátozás 4. Napja [Day 4 of the Lockdown]”. 2020, March 31. Facebook photo album. Retrieved from: https://www.facebook.com/media/set/? vanity=koronavirus.gov.hu\&set=a.124518409158389 (Accessed 08 30, 2020).

Koronavírus tájékoztató oldal (2020). No Title Added. Album: "Kijárási Korlátozás 11. Nap [Lockdown Day 11]". 2020, April 7. Facebook photo. Retrieved from: https://www.facebook.com/koronavirus.gov.hu/photos/a.127490008861229/ 127490012194562 (Accessed 08 30, 2020).

Koronavírus tájékoztató oldal (2020). No Title Added. Album: "Kijárási Korlátozás 6. Nap [Lockdown Day 6]". 2020, April 2. Facebook photo. Retrieved from: https://www.facebook.com/Koronavírus.gov.hu/photos/a.125415902401973/ 125415949068635 (Accessed 08 30, 2020).

Koronavírus tájékoztató oldal (2020). No Title Added. Album: "Lovas Rendör Járörök a Tanyavilágban [Equestrian Police Patrols the Farm World]". 2020, April 20. Facebook photo. Retrieved from: https://www.facebook.com/ koronavirus.gov.hu/photos/a.132495458360684/132497485027148 (Accessed 08 30, 2020).

Koronavírus tájékoztató oldal (2020a). No Title Added. Album: "Protective Equipment Is Coming to the Hospitals in a Row [Sorra Érkeznek a Védöeszközök a Kórházakba]". 2020, April 3. Facebook photo. Retrieved from: https://www.facebook.com/Koronavírus.gov.hu/photos/a. 125849265691970/125849535691943 (Accessed 08 30, 2020).

Koronavírus tájékoztató oldal (2020). No Title Added. Album: "Sok a Munka a Szent János Kórházban Is [There Is Also a Lot of Work at St. John's Hospital]". 2020, April 30. Facebook photo. Retrieved from: https://www.facebook.com/ Koronavírus.gov.hu/photos/a.136684054608491/136684097941820 (Accessed 08 30, 2020).

Koronavírus tájékoztató oldal (2020). Noha Napról Napra Nött a Fertözöttek Száma [Although the Number of Those Infected Increased Day by Day]. 2020, April 3. Facebook post. Retrieved from: https://www.facebook.com/ koronavirus.gov.hu/posts/125774379032792 (Accessed 08 30, 2020).

Koronavírus tájékoztató oldal (2020). Orbán Viktor Miniszterelnök: Tizenharmadik Nap [Prime Minister Viktor Orbán: Day Thirteen]. 2020, March 24. Facebook post. Retrieved from: https://www.facebook.com/ Koronavírus.gov.hu/posts/120910596185837 (Accessed 08 30, 2020).

Koronavírus tájékoztató oldal (2020). Sikeres Volt [It Was Successful]. 2020, June 18. Facebook post. Retrieved from: https://www.facebook.com/Koronavírus. gov.hu/posts/153403529603210 (Accessed 08 30, 2020).

Koronavírus tájékoztató oldal (2020). Újabb Szúrópróbaszerü Ellenörzéseket Tartott [The Government Held Another Random Check]. 2020b, April 24. Facebook post. Retrieved from: https://www.facebook.com/koronavirus.gov. hu/posts/134070131536550 (Accessed 08 30, 2020).

Koronavírus tájékoztató oldal (2020b). "Fábián Bertold Rendör Alezredes [Policeman Lieutenant Colonel Fabian Bertold]." Album: "Védöeszközök És a Kórházparancsnokok Érkeztek a Kórházakba [Protective Equipment and Hospital Commanders Arrived at the Hospitals]". 2020, March 30. Facebook photo. Retrieved from: https://www.facebook.com/koronavirus.gov.hu/photos/ a.124108379199392/124108589199371 (Accessed 08 30, 2020).

Koronavírus tájékoztató oldal (2020a, April 2). "Koronavírus - Maradj Otthon! [Coronavirus - Stay Home!]." Album: "Kijárási Korlátozás 6. Nap [Lockdown
Day 6]". 2020, April 2. Facebook photo. Retrieved from: https://www.facebook. com/Koronavírus.gov.hu/photos/a.125415902401973/125415949068635 (Accessed 08 30, 2020).

Kötelező maszkviselést Kötelező Maszkviselést Hozhat Az Enyhités Magyarországon [Relief Can Bring Mandatory Mask Wearing in Hungary]. April 28, 2020. Infostart. Retrieved from: https://infostart.hu/gazdasag/2020/ 04/28/kotelezo-maszkviselest-hozhat-az-enyhites-magyarorszagon (Accessed $0512,2020)$.

Kötelezővé teszik (2020). Kötelezövé Teszik a Maszkviselést a Budapesti Üzletekben [It Is Mandatory to Wear a Mask in Stores in Budapest]. Index.hu. Retrieved from: https://index.hu/belfold/2020/04/21/karacsony_gergely_maszkviseles_ kotelezo_budapest/ (Accessed 05 12, 2020).

Kovács, B. (2020a). Hogyan Lehetne Megmenteni a Háziorvosi Szakmát Az Elöregedéstöl? July 9, 2020. Mérce. Retrieved from: https://merce.hu/2020/07/ 09/hogyan-lehetne-megmenteni-a-haziorvosi-szakmat-az-eloregedestol/ (Accessed 01 04, 202).

Kovács, K. (2020b). Hungary's Orbánistan: A Complete Arsenal of Emergency Powers. April 6, 2020. VerfBlog. Retrieved from: https://verfassungsblog.de/ hungarys-orbanistan-a-complete-arsenal-of-emergency-powers/ (Accessed $0512,2020)$.

Kováts, E., and Petö, A. (2017). “Anti-gender Discourse in Hungary: A Discourse without a Movement," in Anti-gender Campaigns in Europe: Mobilizing Against equality. Editors R. Kuhar and D. Paternotte (Lanham, Maryland: Rowman \& Littlefield), 117-131.

Krekó, P., and Enyedi, Z. (2018). Explaining Eastern Europe: Orbán's Laboratory of Illiberalism. J. Democracy 29 (3), 39-51.

Krippendorff, K. (2013). Content Analysis: An Introduction to its Methodology. 3rd ed.Thousand Oaks, CA: Sage.

Kuhar, R., and Paternotte, D. (2017). Anti-gender Campaigns in Europe: Mobilizing against equality. Lanham, Maryland: Rowman \& Littlefield.

Laborczi, D. (2020). A Szülók Jogai Is Sérülhetnek a Távoktatás Alatt [Parents' Rights Can Also Be Violated during Distance Learning]. May 12, 2020. Nők Lapja. Retrieved from: https://www.noklapja.hu/aktualis/2020/05/12/szulokjogai-koronavirus/ (Accessed 05, 2020).

Laclau, E. (2006). Ideology and post-Marxism. J. Polit. Ideologies 11 (2), 103-114. Laclau, E., and Mouffe, C. (1985). Hegemony and Socialist Strategy: Towards a Radical Democratic Politics. London/New York: Verso.

Laczó, F. (2018). Populism in Power in Hungary. Consolidation and Ongoing Radicalization. March 27, 2018. Eurozine. Retrieved from: https://www. eurozine.com/populism-power-hungary/ (Accessed 0505, 2020).

Lévai, R. (2018). Közösségi media Adatok 2018 [Social media Data 2018]. February 6, 2018. Közösségi Kalandozások. Retrieved from: https:// kozossegikalandozasok.hu/2018/02/06/kozossegi-media-adatok-2018/ (Accessed 0102, 2020).

Lexicon (2003). Termini ambigui e discussi su famiglia, vita e questioni etiche. [Lexicon. Ambiguous and Debatable Terms Regarding Family Life and Ethical Questions]. Bologna: Edizioni Dehoniane.

Milanovich, D. (2020). A Járvány Máshogy Hat a Nókre, Mint a Férfiakra. De Miért? [The Epidemic Affects Women Differently than Men. But Why?]. March 23, 2020. Dívány. Retrieved from: https://divany.hu/vilagom/2020/03/23/ koronavirus-nok-szempontjai/ (Accessed 0510, 2020).

MTI (2020). Kijárási Korlátozás: Itt Vannak a Részletek [Lockdown: Here Are the Details]. March, 27, 2020. Hiradó.hu. Retrieved from: https://hirado.hu/belfold/ kozelet/cikk/2020/03/27/megjelent-a-kijarasi-korlatozasrol-szolo-rendelet (Accessed 05, 2020).

Nők elleni eröszak (2020). Nök Elleni Eröszak a Járvány Idején - Miért Fokozódik És Hogyan Lehet Tenni Ellene? [Violence against Women during an Epidemic Why Is it on the Rise and How Can it Be Tackled?]. Mérce. Retrieved from: https://merce.hu/2020/04/11/nok-elleni-eroszak-a-jarvany-idejen-miertfokozodik-es-hogyan-lehet-tenni-ellene/ (Accessed 10 05, 2020).

Ónody-Molnár, D. (2020). Szülök a Digitális Oktatásról [Parents on Digital Education]. June 12, 2020. Nők Lapja. Retrieved from: https://www.noklapja. hu/aktualis/2020/06/12/felmeres-digitalis-oktatasrol-karanten-koronavirus/ (Accessed 0510, 2020).

Orbán, V. (2014). Orbán Viktor Beszéde - Tusványos 2014 - Tusnádfürdő [Viktor Orbán's Speech- Tusványos 2014 - Tusnádfürdö]. YouTube video, added by Gergely Molnár. YouTube. Retrieved from: https://www.youtube.com/watch? $\mathrm{v}=$ PXP-6n1G8ls (Accessed 08 30, 2020). 
Orbán (2020). Viktor Napirend Elötti Felszólalása [Viktor Orbán’s Speech before the Agenda]. Facebook video, added by Koronavírus tájékoztató oldal [Coronavirus Information Page]. Facebook. Retrieved from: https://www.facebook.com/ 102141028062794/videos/635446697303221 (Accessed 08 30, 2020).

Özkazanç-Pan, B., and Pullen, A. (2020). "Introduction. Gendered Labour and Work, Even in Pandemic Times" Gender. Work Organ. 2020 (27), 675-676.

Palonen, E. (2018). Performing the Nation: the Janus-Faced Populist Foundations of Illiberalism in Hungary. J. Contemp. Eur. Stud. 26 (3), 308-321.

Palonen, E. (2019). "Rhetorical-Performative Analysis of the Urban Symbolic Landscape: Populism in Action," in Discourse, Culture and Organization. Postdisciplinary Studies in Discourse. Editor T. Marttila (London: Palgrave Macmillan), 179-198.

Pósfai, O. (2020). A Járvány Kezdete Óta Magyarországon Is Jelentösen Megugrott a Családon Belüli Eröszak Bejelentéseinek a Száma [Since the Beginning of the Pandmeic, Reports of Domestic Violence Have Increased Significantly in Hungary as Well]. March 28, 2020. Mérce. Retrieved from: https://merce.hu/ 2020/03/28/a-jarvany-kezdete-ota-magyarorszagon-is-jelentosen-megugrotta-csaladon-beluli-eroszak-bejelenteseinek-a-szama/ (Accessed 05, 2020).

Presinszky, J. (2020). Az Ambiciózus Háziorvos Az Ország Nagymamája Lett [The Ambitious GP Became the Grandmother of the Country]. April 29, 2020. Index. Retrieved form: https://index.hu/belfold/2020/04/29/muller_cecilia_orszagos_ tisztifoorvos_portre/ (Accessed 05, 2020).

Roth, J. (2020). The Pandemic as a Prism: Patterns of En-Gendering and Contestations to Women's and Gender Rights in Times of Corona. October 30, 2020. TRAFO - Blog for Transregional Research. Retrieved form: https:// trafo.hypotheses.org/25082 (Accessed 30, 2020).

Smith, J. (2019). Overcoming the 'tyranny of the Urgent': Integrating Gender into Disease Outbreak Preparedness and Response. Gend. Dev. 27 (2), 355-369.

Strauss, A., and Corbin, J. (1998). Basics of Qualitative Research: Techniques and Procedures for Developing Grounded Theory. 2nd ed. Thousand Oaks, CA: Sage.

Szabó, A. E. (2021). Az Óra Ketyeg. A Tét Óriási - Egy Anyuka Gondolatai Az Április 19-i Isklanyitás Kapcsán ["The Clock Is Ticking. The Stakes Are huge."- A Mom's Thoughts on the April 19 School Opening]. April 9, 2021. WMN.
Retrieved from: https://wmn.hu/ugy/54881-az-ora-ketyeg-a-tet-oriasi-egyanyuka-gondolatai-az-aprilis-19-i-iskolanyitas-kapcsan (Accessed 05, 2021).

Szikra, D. (2018). Welfare for the Wealthy: The Social Policy of the Orbán-Regime, 2010-2017. Budapest: Friedrich Ebert Stiftung.

Ti mit csináltok (2020). Ti mit csináltok, hogy megmaradjon a munkátok, és a gyerek se érezze ezt meg? [What are you doing to keep your job and the child not feel it?]. 11 April 2020. Mérce. Retrieved from: https://merce.hu/2020/04/11/timit-csinaltok-hogy-megmaradjon-a-munkatok-es-a-gyerek-se-erezze-eztmeg/ (Accessed 10 05, 2020).

Townsend, L., and Wallace, C. (2016). Social media Research: A Guide to Ethics. University of Aberdeen, 16.

UNICEF (2020). Hazai Felmérés: Jelentösen Nöttek Az Anyák Terhei a Karantén Alatt [Domestic Survey: Burdens of Mothers Have Increased Significantly during Quarantine]. June 25, 2020. Unicef. Retrieved from: https://unicef.hu/igysegitunk/hireink/hazai-felmeres-jelentosen-nottek-az-anyak-terhei-a-karanten-alatt (Accessed 0508, 2020).

Van Rythoven, E. (2020). What's Wrong with the War Metaphor. April 5, 2020. Duck of Minerva. Retrieved from: https://duckofminerva.com/2020/04/whatswrong-with-the-war-metaphor.html (Accessed 11 25, 2020).

Wizz Air Facebook statistics (2021). Wizz Air Facebook Statistics. Social Bakers. Retrieved from: https://www.socialbakers.com/statistics/facebook/pages/detail/ 115274301883331?url_key=wizz-air (Accessed 04 23, 2021).

Conflict of Interest: The author declares that the research was conducted in the absence of any commercial or financial relationships that could be construed as a potential conflict of interest.

Copyright $\odot 2021$ Linnamäki. This is an open-access article distributed under the terms of the Creative Commons Attribution License (CC BY). The use, distribution or reproduction in other forums is permitted, provided the original author $(s)$ and the copyright owner(s) are credited and that the original publication in this journal is cited, in accordance with accepted academic practice. No use, distribution or reproduction is permitted which does not comply with these terms. 